\author{
Sonia Huderek-Glapska \\ $\mathrm{dr}$ \\ Uniwersytet Ekonomiczny w Poznaniu \\ sonia.huderek@ue.poznan.pl
}

DOI: 10.35117/A_ENG_17_11_01

\title{
What does the success of an airport mean and when it contributes to the regional economy?
}

\begin{abstract}
Until recently airports were seen as part of infrastructure endowment of the country, and their main tasks were to ensure smooth and safe operation of airlines and passenger flow. This situation changed with the liberalization of air transport market and increasing integration and globalization of economies. Competitive environment caused the changes in the model of airport management, preferring increasingly a business approach based on economic calculation. A certain polarization in the development of airports is observed. Some airports enter the path of development and intensive growth, while others are at risk of collapse. The aim of the paper is to define the success of an airport, recognize the factors that have an impact on this success, with particular attention paid to the airlines-airport relationship management and identify the impact of an airport on the urban and regional economy. The problem is gaining importance in view of the pace of change taking place in the business environment.
\end{abstract}

Keywords: Airport management; Company success factors; Airport impact

\section{Introduction}

An airport is an infrastructure facility, but also a complex organization that has the characteristics of an enterprise. Both the infrastructural and economic character of the airport is reflected in the legal definition according to which the airport is an airport, i.e. a separate area on land, water or other surface entirely or partly intended for take-offs, landings and ground or surface water traffic air, along with its permanent construction objects and equipment, entered in the register of airports; public use, used for the payment of transport of passages, baggage, goods or mail [16]. The airport belongs to the hard infrastructure whose use supports the transport sector in the management process. The construction, extension, and use of an airport also contribute to changes in the economic activity of entities from various sectors of the economy, located in the immediate and further vicinity of the airport. At the same time, the airport is managed by a commercial law company, which distinguishes it from other infrastructure facilities such as roads or bridges. An airport is a unit separated in terms of law, economy, and organization. The airport manager runs a business on his own account and focused on generating profit. Due to the strategic role that airports play and continue to play in the defense and development of the country, the vast majority are state-owned, and their market, like the market of all air transport in a significant, and in some areas of activity associated with air transport, to the full extent it's adjustable.

The traditional role of airports is to attract the largest possible number of air carriers and to act as a logistic intermediary between airlines and passengers. Therefore, the strategic and operational purpose of the airport's operation is to maximize air traffic, expressed as the number of air operations, the number of passengers or goods checked in [8]. For the purposes of the airport as an infrastructure provider, airlines are perceived as the main customer of the airport [7]. Along with the changing environment of airports and transformations in the sphere of social, political and economic transformation, the way of managing the airport undergoes 
change, its strategic goals change and the way the airport is perceived by all its stakeholders. In Western Europe, these processes intensified in the 80s of the last century [9]. In Poland, the first changes took place at the beginning of the $90 \mathrm{~s}$, when airports underwent the transformation from facilities managed by central authorities into commercial law companies, the majority of which were mainly local authorities. These changes were parallel to transformations in the economic sphere, and the special dynamics gained with Poland's accession to the European Union, which required the alignment of the law with Community requirements, including aviation law and the opening of markets enabling the free movement of passengers, goods, and capital. The air carriers market has become more competitive, which has led airlines to more control their costs and exert an even stronger impact on airports' airport charges [4]. Thus, airports have begun to seek sources of non-aeronautical revenues and expand their scope of activity with additional products and services, shaping them in such a way as to best suit the needs and preferences of passengers. The strategic goal of airports is to maximize profits and even maximize revenues due to the low cost of servicing an additional passenger by the airport with a simultaneous large share of fixed costs in total costs, which is characteristic for infrastructure facilities.

\section{The success of the airport and its measures}

The success of an airport understood as the achievement of the intended purpose can be variously defined depending on the adopted perspective. Airport stewards, including managers, owners, airlines, passengers, employees, market regulators, entities cooperating with an airport, such as ground handling agents, air traffic controllers, require different information on various aspects of airport operations [7]. An airport can achieve success in one area of its activity while in others it may not achieve its intended goals. The full success of the airport is determined by the fulfillment of all the company's goals set by the manager. In addition to the size of the airport's success, the time dimension is also important. The complex and dynamically changing environment of the airport means that the success achieved can be difficult to maintain in subsequent periods. For this reason, sometimes the success of an enterprise is identified with the organization's ability to develop in a long-term perspective [2]. Development understood as the process of qualitative and quantitative changes taking place over time [12]. The changes may concern both the part and the whole of the enterprise. Thus, the success of an airport is a multidimensional and complex concept depending on the analyzed aspect of the company's operation, the time perspective and the entity that performs the assessment.

In order to identify the success of an airport, it is necessary to apply appropriate measures that provide information on the implementation of the intended objectives and enable assessment of decisions made in the enterprise. A well-designed performance measurement system supports the achievement of strategic, tactical, operational and, if necessary, change of behavioral patterns in the unit's activities [11].

From the point of view of the infrastructure facility, the success of the airport is to ensure efficient and safe movement of aircraft and the flow of passengers and goods. In this context, the measure of airport success is the change in the number of flight operations, the number of passengers checked in, or the number of checked-in goods and mail in a given period of time, compared to the previous period. The growth of these indicators is the success of the airport. From an enterprise perspective aimed at maximizing profit, financial analysis of an airport is the most important system for measuring achievements at an airport. For airport owners, which are primarily self-governments, in addition to self-financing the company, it is important to co-create the development of the city and the region thanks to the airport's operation. The activity of the airport increases not only the availability of the region, it allows 
the flow of passengers and goods but also affects the activity of entities, including the location of enterprises [5].

Table 1 presents different interpretations of airport success depending on the adopted objective of the unit's operation, together with an indication of the type of the measure by which the objective and the main airport stakeholders interested in the implementation of the objective can be measured. Table 1 is complemented by the perspective of airport success of other stakeholders. An example are airport employees, for whom the success of an organization is consistent with their personal professional success, which is achieved when they can carry out the tasks assigned to them with commitment, receive a satisfactory remuneration and their additional needs and preferences will be taken into account [10].

Tab. 1: Characteristics of airport success and its measures

\begin{tabular}{|l|l|l|}
\hline Objective & Gauge type & $\begin{array}{l}\text { Main } \\
\text { stakeholders }\end{array}$ \\
\hline $\begin{array}{l}\text { Ensuring efficient and safe } \\
\text { movement of aircraft and } \\
\text { passenger and goods flow }\end{array}$ & $\begin{array}{l}\text { Number of air operations; } \\
\text { Number of passengers checked in; } \\
\text { Number of checked-in goods and mail }\end{array}$ & $\begin{array}{l}\text { Management, } \\
\text { Owners, } \\
\text { Statistical offices }\end{array}$ \\
\hline Generating profit & $\begin{array}{l}\text { Financial } \\
\text { (Net profit, Profitability ratios) }\end{array}$ & $\begin{array}{l}\text { Management, } \\
\text { Owners }\end{array}$ \\
\hline $\begin{array}{l}\text { Achieving a competitive } \\
\text { position }\end{array}$ & Market share & Management \\
\hline $\begin{array}{l}\text { Creating social well-being } \\
\text { Eumburing adequate } \\
\text { accessibility of the city } \\
\text { and the region }\end{array}$ & $\begin{array}{l}\text { The quantity and quality of air connections } \\
\text { Social costs of aircraft noise and pollution. } \\
\text { (including frequency of flights, type of } \\
\text { carrier) } \\
\text { Journey time to the airport }\end{array}$ & $\begin{array}{l}\text { Passenger } \\
\text { Society, }\end{array}$ \\
\hline $\begin{array}{l}\text { Providing functional and } \\
\text { cost-effective } \\
\text { infrastructure }\end{array}$ & $\begin{array}{l}\text { The amount of air charges; } \\
\text { Number and quality of services offered by } \\
\text { ground handling agents and other entities } \\
\text { providing services to airlines }\end{array}$ & Air line \\
\hline
\end{tabular}

Source: own elaboration

\section{The success of Polish airports}

In order to identify the success of the airport, the airport market in Poland was analyzed. This is an interesting example for analysis for several reasons. Among the countries of Central and Eastern Europe, Poland has the largest number of airports due to its size and population. These airports are in various stages of development. The air transport market is immature, the number of air travel per one inhabitant is almost four times smaller than the average for Western Europe, which proves a high development potential. In the first decade of the $21 \mathrm{st}$ century, the air transport market in Poland was characterized by the highest dynamics of growth in the world. After 13 years since the liberalization of the aviation market, polarization has been observed in the development of airports. Some airports continue the growth path while others are in a phase of stagnation or even decline. In dynamic terms, two specific moments can be observed in the development of Polish airports (Figure 1). The first of these is the year 2004 when Poland joined the structures of the European Union. After this period, the dynamic development of airports is visible due to the entry of new air carriers into the branches and increasing the accessibility of the transport service for a larger group of clients, 
mainly due to the increase in the number of air routes and a significant drop in the price of air tickets. The second significant period is the year 2009 when the aviation market was particularly affected by the effects of the global financial crisis and the volume of transport decreased. Most of the airports later continued the path of growth but with much lower dynamics than in the period 2004-2008. This is typical for maturing markets, where the growth rate over time diminishes with the saturation of the market. It is worth noting that in both cases external factors, such as changes in the political and socio-economic environment of airports, had an impact on their development. Airports reacted differently to these changes. The analysis of the development of Polish airports over a period of two decades makes it possible to distinguish two groups of airports. The first of these are airports serving over 1 million passengers per year: Kraków, Gdańsk, Katowice, Wrocław, Poznań, and Modlin, which was established in 2012. The second group of airports are airports servicing less than 1 million passengers annually, these are: Rzeszów, Szczecin, Bydgoszcz, Lublin, Łódź, Olsztyn, Zielona Góra, and Radom. The correlation between a strong economic center and the level of airport activity is noticeable.

6000000

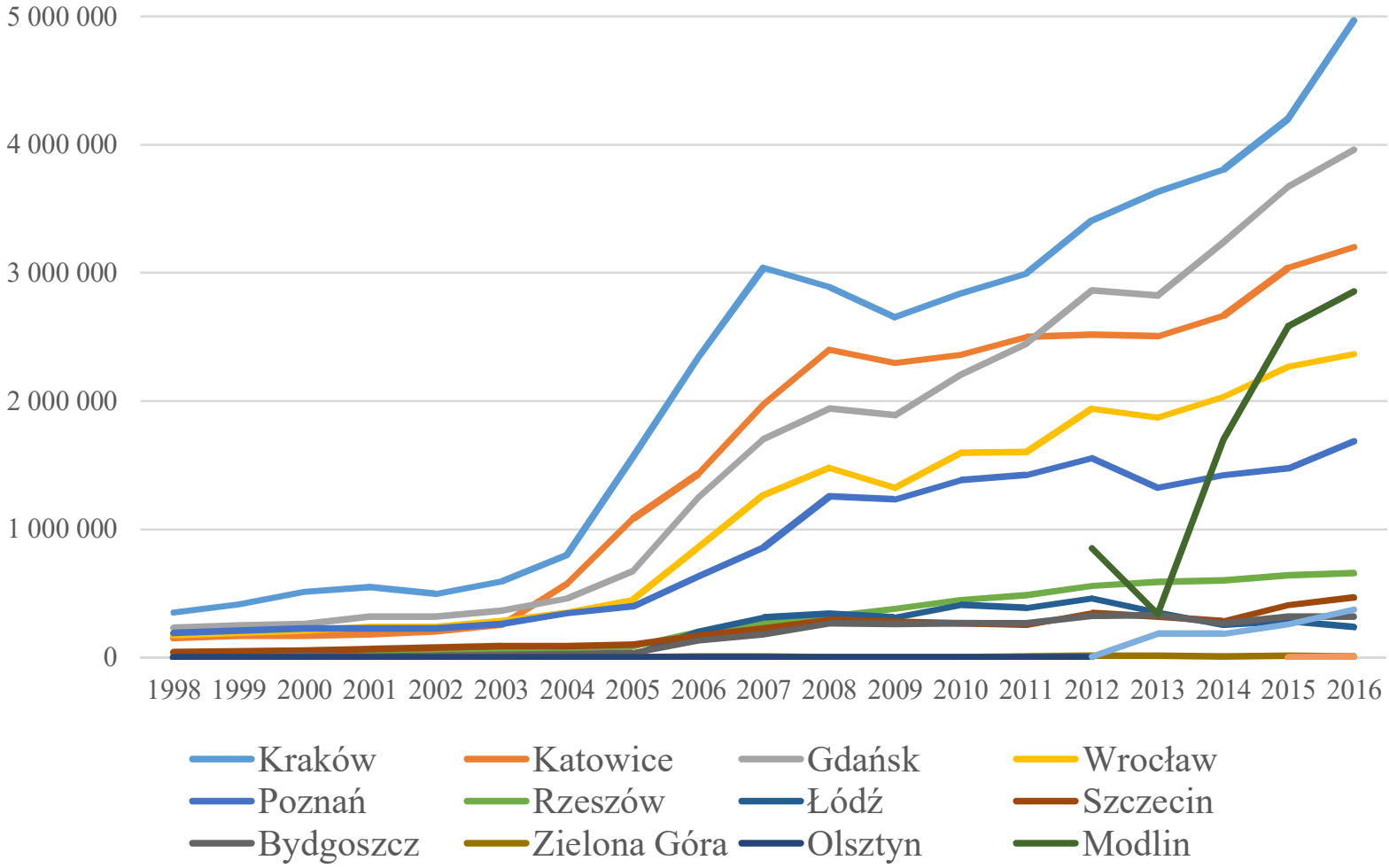

1. The development of Polish regional airports in the years 1998-2016 measured by the number of passengers checked in

Source: Own calculations based on data of the Civil Aviation Office

The analysis of the success of Polish airports has been extended by 6 additional measures (Table 2). In addition to operational measures, financial (revenue, profit) and strategic measures (market share) have been taken into account. The analysis was carried out in a static approach (data from the 2015/2016 period). An in-depth analysis confirmed previous observations. Taking into account the perspective of the airport as an enterprise and 
achieving the goal of generating profit, two groups of airports can be distinguished again. The first group includes airports located in Kraków, Gdańsk, Katowice, Modlin, and Wrocław, these ports in 2015 achieved a positive profit and served over 1 million passengers per year. The only exception is the airport in Poznań, which in 2016 served 1.7 million passengers and did not generate any profit (one of the reasons for this is the high cost of the company to external costs). The ports belonging to the first group together with Poznan together handle more than half of the air traffic in Poland (54\%) and together with Warsaw have a market share of $94 \%$. Other airports in 2015 generated a loss.

It should be noted that the measures used in the above analysis and listed in Tables 1 and 2 relate to the effects of airport operations, and therefore the measurement of achievements takes place in the last stage of the unit's operating process. The reason for measuring the effects (not expenditures or processes) is the observability and measurability of the results of airport activity and the relatively low costs of monitoring and measurement [14]. The disadvantage of the effect meters is the difficulty in recognizing the causes of a given condition and the lack of possibility to change the final state after obtaining information from the measurement process. The manager, receiving data on the number of passengers checked in at the airport during the period under examination, cannot change this number, he does not find out what factors have influenced this figure and what measures he may take in the future to change this number. Only a thorough analysis of the success factors of the enterprise allows identification of the organization's resources and external conditions that contribute the most to the success of the unit's operations.

Tab. 2: Characteristics of Polish airports - static approach

\begin{tabular}{|l|c|c|c|c|c|c|c|}
\hline Airport & $\begin{array}{c}\text { Number of } \\
\text { passengers } \\
\text { (in millions) }\end{array}$ & $\begin{array}{c}\text { Number of } \\
\text { air } \\
\text { operations } \\
\text { (in } \\
\text { thousands) }\end{array}$ & $\begin{array}{c}\text { Number of } \\
\text { passengers } \\
\text { for an air } \\
\text { operation }\end{array}$ & $\begin{array}{c}\text { LCC } \\
\text { traffic } \\
\text { share } \\
(\%)\end{array}$ & $\begin{array}{c}\text { Revenue } \\
\text { per } \\
\text { passenger } \\
\text { (PLN) }\end{array}$ & $\begin{array}{c}\text { Net } \\
\text { profit }\end{array}$ & $\begin{array}{c}\text { Market } \\
\text { share } \\
(\%)\end{array}$ \\
\hline Warszawa & 2016 & 2016 & 2016 & 2015 & 2015 & 2015 & 2016 \\
\hline Kraków & 4,9 & 138,9 & 92 & 23 & 63 & + & 38 \\
\hline Gdańsk & 3,9 & 39,6 & 126 & 71 & 33 & + & 15 \\
\hline Katowice & 3,2 & 23,4 & 116 & 66 & 37 & + & 12 \\
\hline Modlin & 2,9 & 17,5 & 163 & 100 & 18 & + & 8 \\
\hline Wrocław & 2,3 & 20,5 & 116 & 60 & 66 & + & 7 \\
\hline Poznań & 1,7 & 15,2 & 111 & 55 & 34 & - & 5 \\
\hline Rzeszów & 0,6 & 6,2 & 107 & 68 & 80 & - & 2 \\
\hline Szczecin & 0,4 & 4,3 & 110 & 70 & 26 & - & 1 \\
\hline Bydgoszcz & 0,3 & 2,3 & 139 & 85 & 52 & - & 1 \\
\hline Lublin & 0,3 & 2,5 & 146 & 94 & 36 & - & 1 \\
\hline Łódź & 0,2 & 0,9 & 83 & 89 & 60 & - & 1 \\
\hline $\begin{array}{l}\text { Zielona } \\
\text { Gora }\end{array}$ & 0,01 & 0,5 & 17 & 0 & 0 & - & 0,1 \\
\hline Radom & 0,01 & 0,6 & 14 & b.d. & 53 & - & 0,1 \\
\hline Olsztyn & 0,04 & 0,8 & 47 & b.d. & 60 & - & 0,1 \\
\hline Source: & & 0,6 & & 64 & 37 & + & 9 \\
\hline
\end{tabular}

Source: Own study based on data of the Civil Aviation Office and Emerging Markets Informations System 


\section{Management of relations with low-cost airlines as one of the important factors of airport success.}

The success of an airport is determined by factors, both from the inside of the organization, which constitute its resources, as well as those in its surroundings. Proper identification of key factors of airport success allows to improve the process of formulating and achieving strategic goals and thus to intensify the development of the enterprise.

The classification of enterprise development factors depending on the level of analysis includes three groups. The first of them are factors from the macro area, related to the economic situation, the technological and educational environment, the socio-cultural environment and the political and legal situation. The second level of analysis includes factors related to the characteristics of the region and the characteristics of the industry. The last group of factors includes the micro level and refers to the structure of the enterprise, the founder's entrepreneur, the financial situation of the company and its competitive position [13]. These are important factors that are located in the area of influence of the manager, who through their decisions can manage them.

Due to the fact that the airport could not exist without airlines, an important factor in achieving the airport's success in the long-term is acquiring new and maintaining its existing relationships with airlines (maintaining relationships on the business-to-business market is recognized in literature subject as a key driver of the company's success [17] This is a demanding task that the emergence of low-cost operating models has required airport managers to change approaches in negotiations with airlines [15]. the generation of a large number of passengers at the airport means that the air carrier has an advantage in the negotiations, which is strengthened by the competition between the airlines with air carriers [1].The airports use various incentives to attract and retain existing carriers aircraft [3].

In order to analyze the relationship between the airline and the airport, the six largest regional Polish airports were examined [6]. Information was obtained during direct and telephone interviews with airport managers carried out in 2016. The study confirmed that the largest impact on the functioning of the airport in Poland is the air carrier with a low-cost business model (so-called low-cost lines) (Figure 2). The other group in terms of the significance of the impact on the operation of the airport are the remaining regular lines, the airport owner and passengers. In the opinion of half of the airport managers surveyed, maintaining existing and establishing new relations with low-cost airlines is an important factor in the development of the airport [6]. Other managers see the opportunity to develop the airport by strengthening other segments of the airport's operations, such as: the long-haul segment; segment of charter traffic; cargo traffic. The largest Polish regional ports that generate profits have a share of low-cost traffic in air traffic at an average level of $65 \%$ (except the airport in Modlin), while smaller airports (Szczecin, Bydgoszcz, Lublin, Łódź) that suffer financial losses interest rates are much higher at $84 \%$ (Table 2). Such a large dependence on one segment of traffic reduces the negotiating power of the airport and may threaten its development. 


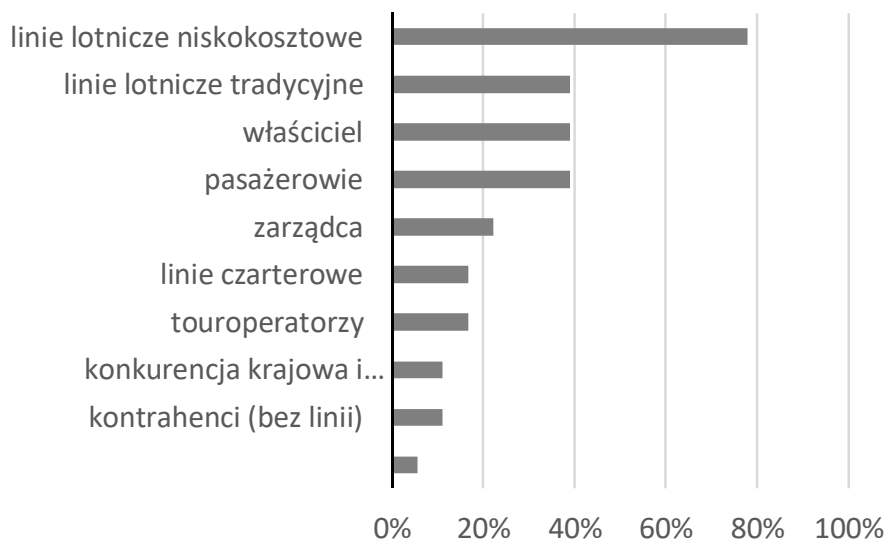

2. Assessment of the impact of stakeholders on the functioning of the airport in the opinion of airport managers $(\mathrm{n}=6)$

Source: [6]

The greatest benefit that airports achieve from cooperation with low-cost airlines is the increase in passenger numbers and the related increase in non-aeronautical revenues (Figure 3). The lack of a sufficient commercial offer at the airport can effectively reduce the benefits of increased passenger traffic. The generation of aviation revenue is only ranked third as a benefit of cooperation with low-cost airlines, which results from the growing pressure of airlines to reduce airport charges at airports.

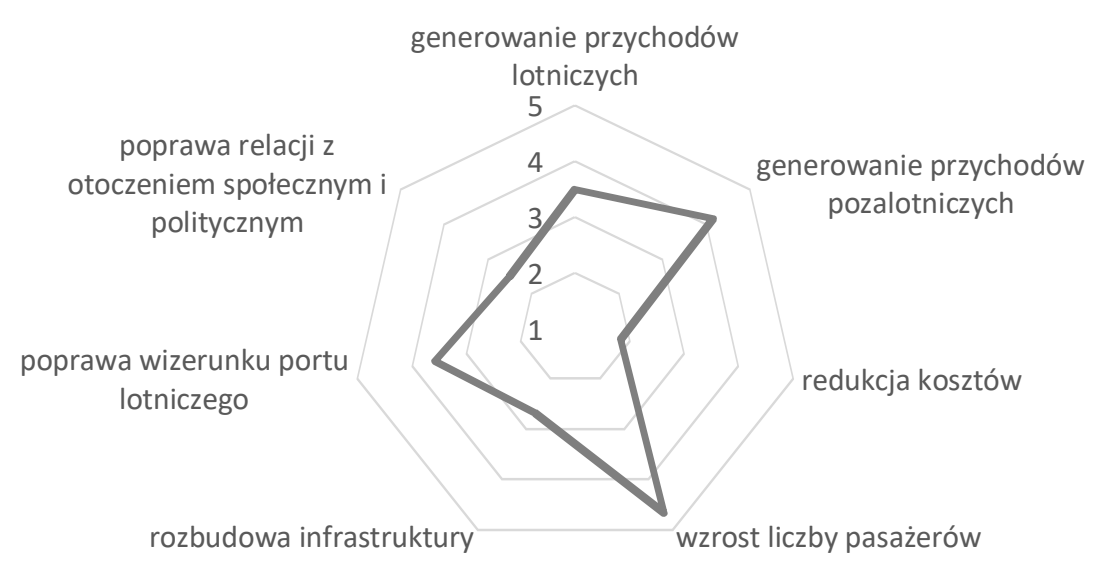

3. The average assessment of benefits that the airport achieves from cooperation with low cost airlines $(n=6)$

Legend: 1 - no benefits, 2- small benefits, 3- moderate benefits, 4 big but not the biggest benefits, 5 - the biggest benefits

Source: [6]

The most important factor that favors maintaining the airport relation with the lowcost line and remains under control and in the area of the manager's decision is to ensure favorable financial conditions for the airline. Guaranteeing favorable financial conditions for the airport was assessed in third place. Airport managers are willing to give up part of the airport's revenue to an airline in order to encourage cooperation. It is worth emphasizing the 
importance of negotiating abilities of airport employees, which proves that employees are an important internal resource for the development of the airport.

Tab. 3: Assessment of the significance of selected factors to maintain long-lasting relations between the airport and the low-cost line, in the opinion of airport managers, $n=6$

\begin{tabular}{|c|c|c|}
\hline Factors & Average & $\begin{array}{l}\text { Standard } \\
\text { deviation }\end{array}$ \\
\hline \multicolumn{3}{|l|}{ In the area of airport management decisions } \\
\hline guaranteeing the best financial conditions for the airline & 4,33 & 0,82 \\
\hline negotiating ability of airport employees & 3,50 & 0,84 \\
\hline guaranteeing the most favorable financial conditions for the airport & 3,17 & 1,33 \\
\hline intense promotional and marketing campaign & 3,17 & 0,75 \\
\hline good financial condition of the airport & 3,00 & 1,67 \\
\hline knowledge of the regulations governing the aviation market & 3,00 & 1,10 \\
\hline knowledge of cultural differences & 2,33 & 1,03 \\
\hline \multicolumn{3}{|l|}{ In the vicinity of the airport } \\
\hline favorable economic situation & 4,00 & 0,63 \\
\hline support for local authorities (public administration) & 3,67 & 1,51 \\
\hline $\begin{array}{l}\text { specific socio-economic characteristics of the region in which the } \\
\text { airport is located }\end{array}$ & 3,33 & 0,82 \\
\hline $\begin{array}{l}\text { building social and personal relationships (eg trust) between the } \\
\text { airline and the airport }\end{array}$ & 3,25 & 1,17 \\
\hline
\end{tabular}

Source: [6]

\section{The goals of the airport and the development of the region}

The airport is an independent organization, managed by a commercial law company, which sets the objectives of the entity's operation based on the economic calculation. At the same time, the airport is an element of the country's infrastructure equipment and supports the transport sector in the management process. In addition, the airport operates in an environment for which it has direct and indirect influence [5]. All these aspects of airport operations cause that not always achieving the company's strategic goals is tantamount to contributing to quantitative and qualitative changes in entities located in the region where the airport operates.

The increase in the number of passengers and the number of airport operations sought by the airport, which is mainly due to low-cost carriers, contributes to the deterioration of the quality of the environment around the airport due to noise and pollution emissions from aircraft. Increased passenger traffic does not translate clearly to the benefits of business entities located in the region. Passenger survey results in Polish regional ports conducted by employees of the Department of Microeconomics at the University of Economics in Poznań have shown that LCCs mainly generate outbound passenger traffic to visit friends and family (VFR), which is among others a consequence of emigration traffic, which is the second largest in terms of size interest in the structure of low-cost airline passengers according to the reasons for traveling. The third largest is the percentage of passengers traveling for tourism. People leaving the region for tourism are more than tourists coming to the region, which results in a negative net balance of tourist effects in the region. 
Attracting and maintaining low-cost carriers at the airport requires guaranteeing favorable financial conditions for the airline. Owners who are local and regional authorities and airport managers bear the financial burden of maintaining cooperation with carriers. In addition, the failure to achieve the goal of maximizing profit by the airport requires local governments to provide financial support to the airport itself.

On the other hand, the development of the airport contributes to the generation of jobs both in entities located at the airport as well as in its immediate and distant surroundings, arouses production from service providers to the airport and related entities, increases the availability of the region and accelerates the flow of passengers, goods and capital, affects the location of enterprises and increase revenues in the region.

\section{Summary}

The changing environment of airports requires management to constantly verify strategic goals. The success of an airport understood as the implementation of objectives depends, inter alia, on the perspective of stakeholders. There are many factors that contribute to the success of the airport. The most important, under the control of the manager, are human resources, including the skills and competences of employees. An important factor that belongs to the environment of the airport is the favorable economic situation of the region in which the airport is located. Negotiation skills of employees are conducive to gaining new and maintaining current relations with low-cost airlines, which to a large extent contribute to the goal of the airport, which is the increase in the number of passengers. The activity of low-cost carriers at the airport does not translate into an increase in airline revenues, therefore airport managers are looking for sources of additional non-aeronautical revenues and diversification of business segments, so as not to be dependent only on one segment. This has a positive impact on the company's profit generation.

The development of the airport entails positive and negative effects that arise in the environment of the entity. The measurement of airport performance can, therefore, be assessed not only on the basis of economic criteria but also social criteria, including environmental ones. The experience of many airports shows that maintaining good relations with airport stakeholders, not only air carriers, but also owners, employees, and the local community, through activities within socially responsible business is a value that favors the achievement of the airport's success.

The work was created as a result of the research project No. 2015/17 / D / HS4 / 00363 financed from the funds of the National Science Center.

\section{Source materials}

[1] Barbot C. Low-cost airlines, secondary airports, and state aid: An economic assessment of the Ryanair - Charleroi airport agreement. Journal of Air Transport Management, 2006, 12(4), 197-203.

[2] Drucker P. Zarządzanie w XXI wieku. Muza S.A. Warszawa 2000

[3] Francis G., Humphreys I., Ison, S. Airports` perspectives on the growth of low cost airlines and the remodeling of the airport-airline relationship. Tourism Management, 2004, 25(4), 507-514.

[4] Graham A. How important are commercial revenues to today's airports? Journal of Air Transport Management, 2009, 15, 106-111.

[5] Huderek-Glapska S. Oddziaływanie portu lotniczego na gospodarkę regionu. Przegląd Komunikacyjny, 2012, 2, 20-25 
[6] Huderek-Glapska, S., Nowak, H. Airport and low-cost carrier business relationship management as a key factor for airport continuity: The evidence from Poland. Research in Transportation Business \& Management, 2016, 44-53.

[7] Humphreys I., Francis G. Performance measurement: a review of airports. Interational Journal of Transport Management, 2002, 1, 79-85.

[8] Jarach D. The evolution of airport management practices: towards a multi-point, multiservice, marketind-driven firm. Journal of Air Transport Management, 2001, 7, 119125 .

key to successful relationship management? The Journal of Business \& Industrial Marketing, 2002, 17(7), 575-597.

[9] Kim H., Shin J. A contextual investigation of the operation and management of airport concessions. Tourism Management, 2001, 23, 149-155.

[10] Kopertyńska M. W., Kmiotek K. Zaangażowanie pracowników a sukces organizacji. Zarządzanie i Finanse, 2016, 14, 2, 183-194.

[11] Kotłowska M., Kowalak R. Kluczowe mierniki dokonań w zarządzaniu przedsiębiorstwem. Wydawnictwo Uniwersytetu Ekonomicznego we Wrocławiu, 2016.

[12] Machaczka J. Zarządzanie rozwojem organizacji. Czynniki, modele, strategia, diagnoza. Wydawnictwo Naukowe PWN, 1998.

[13] Nowak H. Determinanty przetrwania nowo tworzonych przedsiębiorstw w województwie wielkopolskim - podejście instytucjonalne, Praca doktorska. Uniwersytet Ekonomiczny w Poznaniu, 2013.

[14] Simons R. Performance Measurement \& Control System for Implementing Strategy. Prentice Hall Upper Saddle River, New Jersey, 2000.

[15] Starkie D. European airports and airlines: Evolving relationships and the regulatory implications. Journal of Air Transport Management, 2002, 21, 40-49.

[16] Ustawa z 3.7.202 - Prawo lotnicze. Dz. U. z 2016 r. Poz. 605 ze zm.

[17] Zolkiewski J. Turnbull P. Do relationship portfolios and networks provide the key to successful relationship management?. Journal of Business and Industrial Marketing, $2002,17,7,575-597$ 